\title{
Comparative study of agro-based small scale industries in Punjab
}

\author{
Balvinder Singh, Ph.D.Scholar, IK Gujral Punjab Technical University, Kapurthala, Punjab, \\ India.baladv40@gmail.com \\ Dr. Shashi Shekhar Professor Quest Group of Institutions, Jhanjeri, Mohali, Punjab, India. \\ shashishekhar26feb@gmail.com
}

\begin{abstract}
About 70\% population of Punjab is earning from agriculture. In Punjab there is unemployment, and agro-based small scale industries can help to control the problem. Secondary data which is collected from the statistical department Punjab are used. An attempt is made to compare the agro-based small scale industries in Punjab with the small scale industries in Punjab. The results show that the trend of growth in both industries are the same. Correlation analysis shows that there is a positive correlation of production with the fixed investment, production and employment in both the industries. Results show that production is growing in both the industries. Number of units in the agro-based small scale industries has decline in small numbers whereas in small scale industries it has increase in small numbers.
\end{abstract}

Key Words:- Growth, Small scale industries, agro-based small scale industries, agro-based, employment generation, production, employment, fixed investment.

\section{INTRODUCTION}

Small Scale Industry is the industry where the total capital employed in the plant and machinery is a minimum of Rs.2.5 million and the maximum is Rs.50 million in case of manufacturing unit.

1. Agro-based Industries:- These industries are based on the processing of agriculture produce or they cater to input need for agriculture. Some of these are food products, beverage, textiles and dying, hosiery, wood products, paper and printing, leather products, handloom, oil industries, sugar mills, bricks manufacturing, fertilizer, etc

\section{IMPORTANCE OF THE STUDY}

Punjab is an agricultural state majority of industries are agro-based. By encouraging the agro-based will directly help the farmers. Farmers of Punjab are committing the suicides because of poverty.

\section{LITERATURE REVIEW}

1. (Malkar, 2019) Objective was to study the organization of industries, to study the problem, and future prospects. Random sampling technique used to collect the sample objective of research to seek into problems of industries to improve the effectiveness of the system to test the existing belives to expand the knowledge the organizational structure of industries to study the analysis to test a hypothesis, Finding of the study is correlation small industries has a problem with marketing and finance.

2. (Ramachandra 2016 ) As per the researcher, agro-base industries have a strong link with agriculture. Object of the study and economic growth to study marketing and financial practice and problems to know the extent of sickness. The researcher has used the primary and secondary data, Researcher has used Gp ratio, Debt equity ratio, Quick ratio, Interest coverage ratio and capital turn over ratio. Researcher suggests poor marketing, packaging, poor Quality are the main problems Researchers has used $\mathrm{z}$ test,ANOVA and $\mathrm{f}$ test to test hypothesis.

3. (Gulve 2016 ) Research is of the view that small scale agro-based industries are a tool for rural transformation. Research is of the view that this indirectly is easy to low investment, it directly helps the farmers. Objective of the study was to study the infrastructure for growth of industries, to study the non-agriculture determinant period under study was 1970-71 to $1994-95$ primary data was collected with the help of questionnaire. Author used the percentage to show the major data, Author tells There is a shortage of raw material lack of, finance marketing and training problem, to study the working capital and future prospectus. The researcher has used correlation

4. (Sethi 2012) According to the researcher, Punjab is the agriculture surplus state, but it is lacking in industrialization. Researcher had examined the growth of 27 years 
starting from 1980-81 to 2006-2007, Techniques used exponential growth rate, coefficient of concordance cobb Dugles production function, the researcher has used the secondary data, the study suggests that the production base was slipping. The researcher has used the old data. No attention is given to the problem of the agro-based small scale industries in Punjab.

5. (Kumar, 2013) The researcher is of the view small scale industries has a major share in the production and export. Small scale industries was not much affected by the liberalization and globalization. In this study, secondary data are used. The author suggests that the government should help these industries to make it competitive.

6. (MeKeller, and Smardon, 2012) The researcher conducted the study in San Andrae's province and the Santa Catalina study was conducted through a survey and the interview method. Researchers are of the view by promoting and supporting the family business of agrobased we can enhance the livelihood of the people. The object of the study was to know the ability of the industries to cope and recover from stress and shocks to enhance capability for present and future potential to contribute to net wealth. Researcher used the convenience sampling method of 30 units. A close-ended questionnaire using the literate rate scale was used for quantitative and qualitative data. This study suggested that for making industries sustainable agriculture should be strengthened. The study suggested agro-industry is facing the challenges that constraint its sustainability.

7. (Sharma, 2012), is of the view prosperity and happiness can be achieved only through economic activities according to the author small Scale Industries to provide employment and a strong industrial base. The small sector should be promoted instead of giving protection. The researcher has pointed out the scientific marketing approach. The study also points out the problems of small scale industries. The researcher has used primary and secondary data, primary data collected by random multistage sampling, used mean, standard deviation and t-test. The object of the study was to find the problem of exporting and non-exporting units.

8. (Gupta, 2009) suggest that the industry will observe low growth in units and employment. The researcher has used the autoregressive integrative moving average for prediction. Author suggests that the government should take steps to improve the small scale industries. Object of this study is to forecast the units, employment, fixed capital and production of small scale industries in Punjab.

9. (Garg, 1996), suggest small scale industries have better utilization of scare capital. This industry is more labour-intensive. Researcher is of the view that share of small scale industries in total production is decreasing as compared to the large scale industries. Small scale industries have not access to information as compared to the large industries. The government should encourage those industries which perform well in the production and exports. The study is based on secondary data Researcher has used trend analysis and average annual growth rate for analysis and interpretation of data.

10. (Wardena, 1994) suggest that more skilled labour have better performance. Small scale industries contributes $90 \%$ of the total industry in devolved and devolving countries. Type of industries play an important role in the growth of its subgroup. Causes of failure vary from country to country, researchers conducted the study through questionnaires and used T-test, F test, and regression analysis. Object of the study was to examine the variable that has an impact on the growth. In Japan, a bigger firm is performing better than the smaller firms. Selling in the domestic market is profitable for Japanese firms due to the durability of the Yen. The result of the study suggests that the chemical industry is performing much better Authors have used regression analysis and variables taken are the age of the firm, research, and development and capital availability.

\section{GAP IN RESEARCH}

No latest study in Punjab, Researchers have analyzed the very old secondary data and researcher has not covered the entire Punjab for the primary data collection

\section{RESEARCH METHODOLOGY}

Research is descriptive research, Secondary data a re used and data collected from the statistical department Punjab and industries department of Punjab. Data is from the financial year ending 2003 to fiancial year ending 2018. Tools that have been used are trend analysis and for ratio analysis average annual growth ratio is calculated. For correlation analysis Eview9 software is used, the result shows that there is no correlation between number of units and output in both the industries and positive correlation of production with fix investment, production and employment in both the industries. Software used is Excels and Eview 9.

\section{OBJECT OF STUDY}

To comparatively study the growth of agro-based small scale industries in Punjab with the small scale industries in Punjab.

\section{HYPOTHESIS}

1. If industries are growing its subgroup will also grow i.e. if small scale industries is growing its sub group ie agrobased small scale industries will also grow. 


\section{DATA ANALYSIS}

\section{Figure No 1 TREND ANALYSIS}

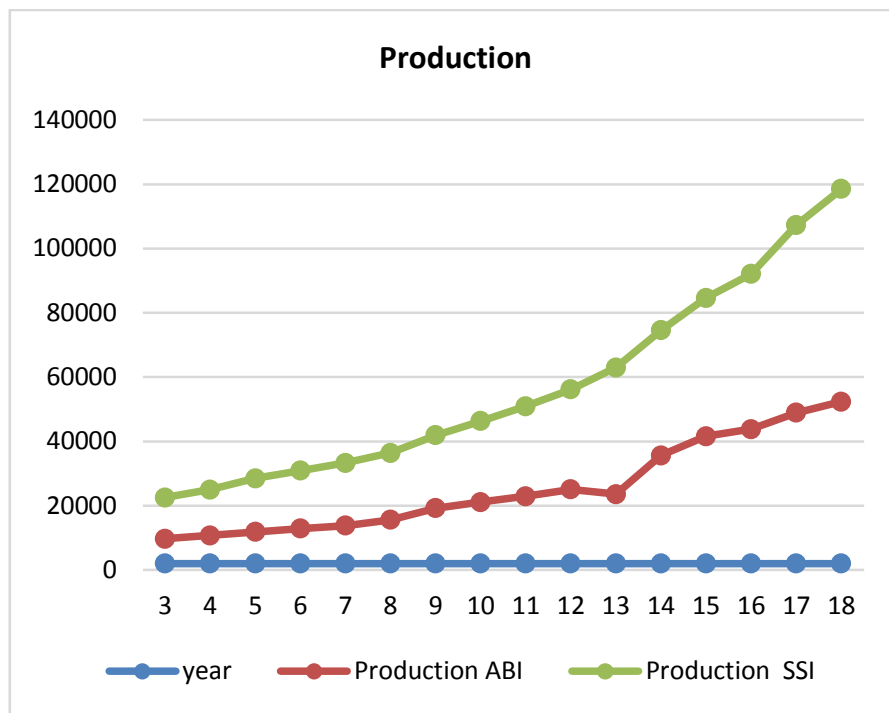

As per the above figure production for the year 2003 of agro-based small scale industries were Rs.9703.52 crore. And it slightly declines in 2013 and again started to show the upward trend in the year 2018 it was Rs.52380.78 crore, showing a net increase of Rs.42677.26 crores

And in the case of small scale industries in the year 2003 production was Rs.22524crore and it in the year 2018 it were Rs.118572.14 crore showing upwards trend net increase of Rs.96048.14crore

Figure No . 2

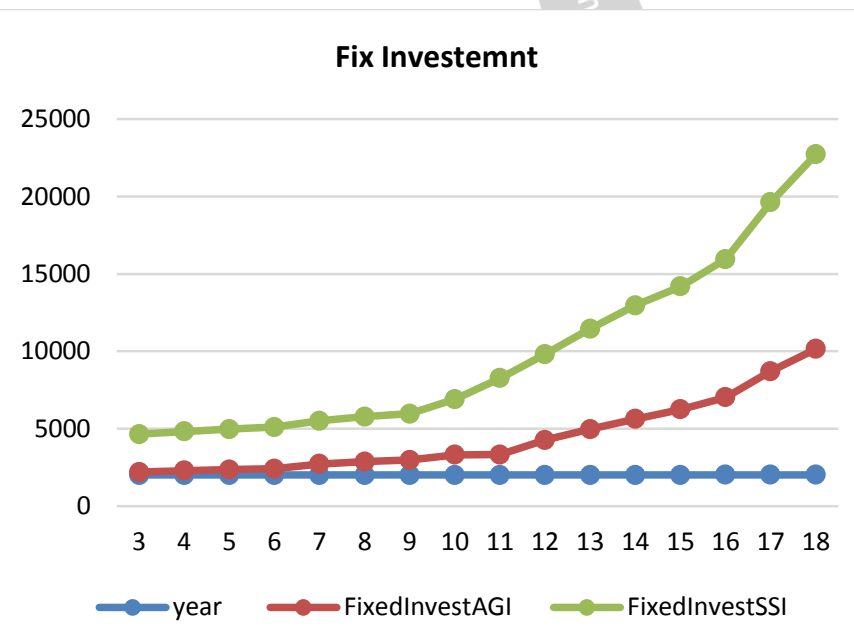

In the case of agro-based small scale industries fix investment for the year 2003 were Rs.2197.23crore it shows the constant upward trend and in the year 2018, it was Rs.10155.52 cores showing the net increase of Rs.7958.29crore.

And in the case of small scale industries, it was Rs.4041crore in the year 2003 showing the upwards trend it the year 2018 it were Rs.22726.01crore showing the net increase of Rs.18085.01crore.
Figure No. 3

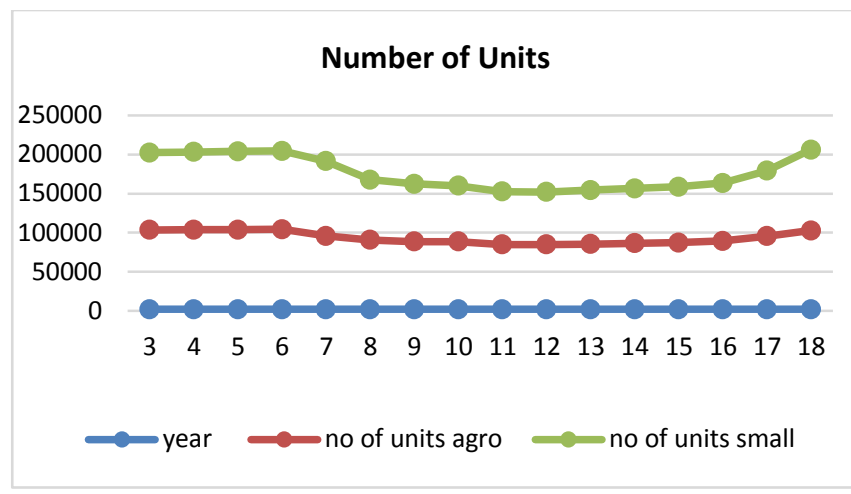

In the case of agro-based small scale industries, it was Rs.103632crore in the year 2003 showing the upwards trends up to the year 2006 when it was Rs.104397crore and started to decline up to the year 2012 when it was Rs.84781crore and after that, it started the upwards trend and in the year 2018, it were Rs.102727crore net decline in 16 years 905 units.

And in the case of small scale industries in the year 2003 it was Rs.202537crore it continues to show increase up to 2006 after that it started to decline up to the year 2012 after that it started to upward trend in the year 2018 it was Rs.26095crore net increase in 16 years 3558 units

Figure.No. 4

\section{Employment}

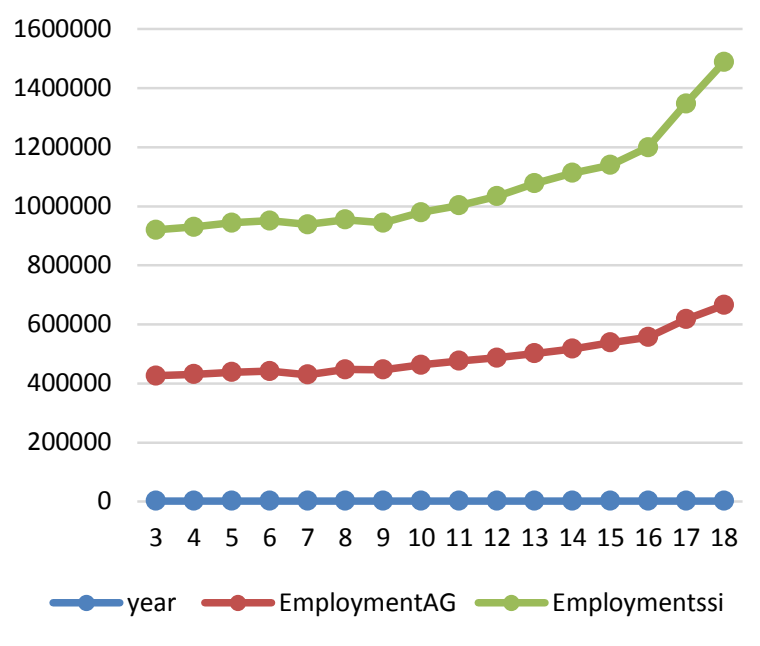

In the case of agro-based small scale industries employment in the year, 2003 were 426383 and it is showing the upward trend and in the year 2018 it were 665208 net increase of 238825

In the case of small scale industries in the year 2003 employment were 920077 showing the constant upward trend in the year 2018 it were 1487843 showing the net increase of 567766 
Table No. 1 COMPARATIVE STUDY OF AVERAGE ANNUAL GROWTH RATE

\begin{tabular}{|l|l|l|l|l|}
\hline $\begin{array}{l}\text { Type of } \\
\text { industries }\end{array}$ & Units & Employment & $\begin{array}{l}\text { Fixed } \\
\text { Investment }\end{array}$ & Production \\
\hline abssi & $-0.05 \%$ & $3.73 \%$ & $24.14 \%$ & $29.32 \%$ \\
\hline ssi & $0.11 \%$ & $4.11 \%$ & $25.97 \%$ & $28.42 \%$ \\
\hline
\end{tabular}

As per the above table average annual growth in the case of agro-based small scale industries in Punjab in the case of units is -0.05 , employment $3.73 \%$, fixed investment $24.14 \%$ and production is $29.32 \%$

And in the case of small scale industries average annual growth of Units is $0.11 \%$, employment $4.11 \%$, fixed investment $25.97 \%$ and production $28.42 \%$

\section{CORRELATION ANALYSIS}

Table No.2 AGRO-BASES SMALL SCALE INDUSTRIES IN PUNJAB

\begin{tabular}{|l|l|l|l|l|}
\hline & prod & Units & $\begin{array}{l}\text { Fixed } \\
\text { invest }\end{array}$ & Employment \\
\hline Prod & 1 & -0.286818 & 0.977229 & 0.966654 \\
\hline Units & -0.286818 & 1 & -0.131644 & -0.101739 \\
\hline Fixed invest & 0.977229 & -0.131644 & 1 & 0.994268 \\
\hline Employment & 0.966654 & -0.101739 & 0.994268 & 1 \\
\hline
\end{tabular}

As per the above correlation analysis, there is no correlation between no of units and production, fixed investment or employment, production and fixed invest has .97coreelation and employment has .96 correlation ie high correlation

Table No.3 CORRELATION ANALYSIS SMALL SCALE INDUSTRIES IN PUNJAB

\begin{tabular}{|c|c|c|c|c|}
\hline & prod & Units & Fixed invest & $\begin{array}{l}\text { Employmen } \\
\mathrm{t}\end{array}$ \\
\hline Prod & 1 & $\begin{array}{l}- \\
0.2387314 \\
1\end{array}$ & $\begin{array}{l}0.99176372 \\
5\end{array}$ & $\begin{array}{l}0.96519379 \\
2\end{array}$ \\
\hline Units & $\begin{array}{l}- \\
0.23873141\end{array}$ & 1 & $\begin{array}{l}- \\
0.14493631\end{array}$ & $\begin{array}{l}- \\
0.00903869\end{array}$ \\
\hline Fixed invest & $\begin{array}{l}0.99176372 \\
5\end{array}$ & $\begin{array}{l}- \\
0.1449363 \\
1\end{array}$ & 1 & $\begin{array}{l}- \\
0.00903869\end{array}$ \\
\hline $\begin{array}{l}\text { Employmen } \\
\mathrm{t}\end{array}$ & $\begin{array}{l}0.96519379 \\
2\end{array}$ & $\begin{array}{l}- \\
0.0090386 \\
9\end{array}$ & $\begin{array}{l}0.98587572 \\
7\end{array}$ & 1 \\
\hline
\end{tabular}

As per the above correlation analysis table, production and fixed investment have .99 correlation, production and employment have .96 correlation. number of units has no correlation with any other variable fixed investment and employment has a correlation of .98

This analysis proves the hypothesis that both the industries is having the same trends and same type of correlation i.e. behaving in the same way

\section{v. CONCLUSION AND RECOMMENDATIONS}

Production is considered as a measure for growth and not the number of units. ie industries. In both the industries production is growing in agro-based small scale industries average growth rate is $29.32 \%$ and in the small scale industries is $28.42 \%$ just close to each other. Average growth rate of fixed investment in agro-based small scale industries is $24.14 \%$ and in small scale industries is $25.97 \%$. Correlation analysis of agro-based small scale industries show a high positive correlation of production and fixed investment, production and employment, production and number of units no correlation. And in the case of small scale industries high positive correlation of production and fixed investment, production and employment and no correlation of production and number of units. Agro-based industries directly affect the income of the farmers, the financial condition of farmers is not good. Government should help the agro-based small scale industries to help the farmers.

\section{REFERENCES}

[1] V. R. Malkar, 'A critical study of organisation structure problems and future of small scale agro_base industries with special reference to Ahmednagar district' 2019. Avilable at http://handle.net/10603/252487.

[2] S. Kumar, 'GROWTH PERFORMANCE OF SMALL SCALE INDUSTRIAL SECTOR IN PUNJAB AND HARYANA - AN INTER TEMPORAL ANALYSIS Section-I', 2013.avilable at

http://shodhganga.inflibent.ac.in/bitstream/10603/1 1/11 chapter4.pdf

[3] M. M. M. M. and R. C. Smardon, 'The Potential of Small-Scale Agro-Industry as a Sustainable Livelihood Strategy in a Caribbean Archipelago Province of Colombia', J. Sustain. Dev., vol. 5, no. 3, 2012. DOI:10.5539/jsd.v5n3p 16.

4] R. Sharma, 'Problems and Prospects of Small Scale Industrial Units (a Case Study of Exporting and Non - Exporting Units in Haryana)', IRJC Asia Pacific J. Mark. Manag. Rev., vol. 1, no. 2, pp. 191-210, 2012.

[5] A. S. Sethi, 'Performance of Small-Scale AgroBased Industry in Punjab: Need for its Revival', Res. J. Soc. Sci., vol. 19, no. 3, pp. 01-14, 2012.

[6] S. Gupta, 'Future Prospects of Small Scale Industrial Sector Of Punjab: An Empirical Assessment', vol. 7, pp. 102-110, 2009.DOI :ISSN1943-7765 
[7] M. A. Ramachandra, 'A study of performance and problems of marketing and finance of small scale agro processing industry with special reference to Ahmednagar district' 2016.avilable at http://handle.net10603/93692

[8] M. Gulve, 'Study of small scale agro based industries in beed district m s' Aurangabad, 1999. avilable at http://handle.net/10603/104627

[9] C. C. Garg, 'Growth of small scale industries in India: Some policy issues', Work. Pap., no. 96/10, pp. 15-18, 1996.avilable at http:ifrsd.repce.org/p/npf/wpaper/96-10.html

[10] H. \& C. S. Wardena, 'Determinants of growth in small manufacturing firms: The Japanese experience', Res. onliine, vol. paper 2, pp. 1-12, 1994.

\section{WEBSITES}

www.business.gov.in/ small scale industries in India (Accessed on 10 November 2016)

www.dcmsme.gov.in/sido (Accessed on 1 April 2019)

www.msme.ac.in:/ (Accessed on 1 April 2019)

www.oxfordscholarship.com/small scale industries (Accessed on 1 April 2019) 